\title{
Effect of Ph Changes on the Corrosion Resistance of Anodizing Titanium Dental Implant with Cobalt Chromium Bar Attachment
}

\author{
Narjes Fadel Mohsen ${ }^{1}$, Magdi Abd El-Meguid Awadallah², Seham Ahmed Hanafy ${ }^{3}$ \\ ${ }^{1}$ BDS, Faculty of Dentistry, Tripoli University, MS, Alexandria University, Egypt \\ ${ }^{2}$ Professor of Prosthodontics, Alexandria University Faculty of Dentistry, Alexandria, Egypt \\ ${ }^{3}$ Professor of Dental Materials Faculty of Dentistry University of Alexandria, Egypt
}

\begin{abstract}
Introduction: When two or more dental prosthesis devicelrestoration made of dissimilar alloys come into contact while exposed to oral fluids, the difference between their corrosion potential results in a flow of electrical current between them. An in vivo galvanic cell is formed and the galvanic current causes acceleration of corrosion of the less noble metal. The galvanic current passes through the metaAmetal junction and also through tissues, which cause pain. The reduction of the PH and the presence of fluid are two essential factors in the initiation and propagation of the corrosion with dissolve of the passive layer of the alloy that accelerate local corrosion process. To overcome the problem of metal release as a result of corrosion, Anodic oxidation is commonly used surface treatment. Anodizing is an electrolytic oxidation process for thickening the oxide layer on active titanium metals. Aim of study: Study the effect of PH changes on metal release, and surface characteristics of anodizing titanium implant with cobalt chromium bar attachment (in vitro study). Material and methods: Three parallel groups 6 specimens each, will be examined. Group A, Group B, Group C. All groups will be subjected to 2 different tests to evaluate 1. Metal release, 2. Surface characteristic.(three implants and three bars as control group for scanning electron microscopic to study surface characteristic. Results: Significant differences between groups and less corrosion resistance was in acidic pH5 group, and there was no significant difference between normal pH 6.8 and alkaline pH8 groups.
\end{abstract}

Keywords: titanium dental implant, cobalt chromium bar, $\mathrm{pH}$ change, corrosion resistance, metal release

\section{Introduction}

The most commonly used implant $\backslash$ prostheses materials today are titanium and cobalt chromium. [1,2] Due to their excellent biocompatibility, high strength, rigidity and resistance to corrosion due to adherent layer of chrome based oxide on surface of cobalt chromium and oxide layer on titanium. [3-5] In spite of protective surface, titanium and cobalt chromium not immune to corrosion attack when placed in contact with body fluid. [6] The reduction of the $\mathrm{pH}$ is essential factors in the initiation and propagation of the corrosion with dissolve of the passive layer of the alloy that accelerate local corrosion process. The oral cavity is constantly subjected to changes in the $\mathrm{pH}$ and that such environment is strongly corrosive for metallic restorations, in which the metal is attack by presence of natural agent (air and water) and ph changes because of diet and drug. [7,8] The PH scale goes from 0-14 (with acidic substance falling below 7 and basic substance falling above 7). There is controversy about the galvanic corrosion of titanium in contact with cast alloys some reported no current or changes in $\mathrm{pH}$ registered when cobalt chromium metallic contact with titanium [9.10] other reported when acidity increased the passive layer of the alloys can dissolve and thus accelerate corrosion when titanium connected to cobaltchromium alloys. [11] The most common form of corrosion which generally present in dental implant is galvanic corrosion. [6] When two or more dental prosthesis device $\backslash$ restoration made of dissimilar alloys come into contact while exposed to oral fluids, the difference between their corrosion potential results in a flow of electrical current between them. An in vivo galvanic cell is formed and the galvanic current causes acceleration of corrosion of the less noble metal. The galvanic current passes through the metal $\backslash$ metal junction and also through tissues, which cause pain. The current flows through two electrolytes, saliva, or other liquids in the mouth and the bone and tissue fluids. [12] Another form of corrosion which leading to galvanic corrosion is pitting corrosion. Pitting corrosion is a form of extremely localized corrosion that leads to the creation of small holes in the metal. [13] It usually occurs on the base metals, which are protected by naturally forming, thin film of an oxide. The material used must not cause any biological adverse reaction and must retain its form and properties during function. [14] Extensive release of metal ions from human body implant can result in adverse biological reactions and even lead to mechanical failure of the device. [15] To overcome the problem of metal release as a result of corrosion, Anodic oxidation is commonly used surface treatment. Anodizing is an electrolytic oxidation process for thickening the oxide layer on active titanium metals. [16] Anodic oxidation is a surface improvement technique for titanium dental implants which is very cheap, and also enables the formation of uniform coatings on the surface. [17] Passive layers which are formed during anodic oxidation are more stable than oxide layers which are formed on the metal surface in contact with air. [18] Because its metal surfaces are covered by a very thin oxide layer in contact with air. This very thin layer of high porosity and low mechanical strength cannot protect metal against corrosion. [19] 


\section{International Journal of Science and Research (IJSR)}

ISSN (Online): 2319-7064

Index Copernicus Value (2013): 6.14 | Impact Factor (2015): 6.391

\section{Material and Methods}

In this in vitro study, was carried out to evaluate metallic ions released and surface characteristic of anodizing titanium dental implant in contact with cobalt chromium bar in a period 7, 30 days. Dental casting alloys are given in table 1 .

Table 1: Composition of studied dental alloys

\begin{tabular}{|c|c|}
\hline Casting alloys & $\begin{array}{c}\text { Composition \& proportion of ingredient by } \\
\text { weight }(\%)\end{array}$ \\
\hline Ti6ai4(ti101) & $\mathrm{Ti}=89+\mathrm{Al}+\mathrm{V} 4+$ trace element 1 \\
\hline Co-cr (bego) & $\mathrm{Co}=62,5+\mathrm{cr}=29,5+\mathrm{mo}=5+(\mathrm{si}+\mathrm{mn}+\mathrm{fe}+\mathrm{n}+\mathrm{c}<1)$ \\
\hline
\end{tabular}

\subsection{Preparation of Sample}

Eighteen dental implants (9 model each model 2 dental implants with bar). The two titanium implants were inserted within acrylic block with adequate space in between (20$22 \mathrm{~mm}$ ). The collar section of the implant flushed with the model cast. A cobalt chromium bar was constructed in conventional manner (castable bar system) connecting the two implants and attached to it with titanium screws (fig.1). The blocks of acrylic resin with dental implant and cobalt chromium bar classified into three groups as regards to $\mathrm{pH}$ artificial saliva. group A: (normal $\mathrm{pH}(6,8)$ artificial saliva). Group B (acidic pH (5) artificial saliva). Group C (alkaline $\mathrm{pH}(8)$ artificial saliva) .composition of artificial saliva are given in table 2 .

Table 2: Composition of artificial saliva at initial $\mathrm{pH} 6.8$

\begin{tabular}{|c|c|}
\hline Component & Quantity \\
\hline $\mathrm{Na} 2 \mathrm{HPO} 4$ & $0.260 \mathrm{~g} / \mathrm{l}$ \\
\hline $\mathrm{NaCle}$ & $0.700 \mathrm{~g} / \mathrm{l}$ \\
\hline $\mathrm{KSCN}$ & $0.330 \mathrm{~g} / 1$ \\
\hline $\mathrm{KH} 2 \mathrm{PO} 4$ & $\mathrm{O}, 200 \mathrm{~g} / 1$ \\
\hline
\end{tabular}

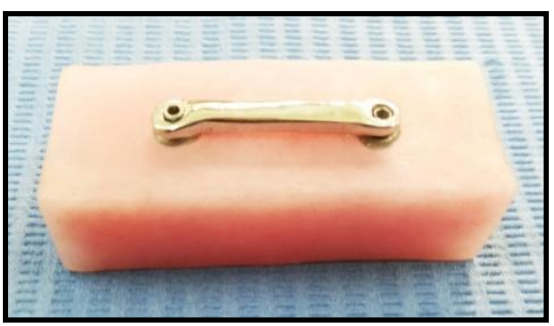

Figure 1: Acrylic block with 2dental implants and bar attachment.

\subsection{Analytic Method}

Inductive coupled plasma atomic emission spectrophotometer (ICP)

Inductive coupled plasma atomic emission spectrophotometer (ICP) was used for analyzing the artificial saliva sample. ICPspectrophotometer is analytic technique that performs element analysis with excellent sensitivity. It can measure most elements in the periodic table, then determine, and analyze their concentration. The mean amount of different element released from alloys were determined and presented in part per million (ppm)

\section{Scanning electron microscopic}

Is technique which is commonly used for the analysis of different metallic materials microstructure before and after corrosion attack, as well as for surface layer morphology examination.

\section{Statistical Analysis}

The resulting data were fed to the computer and analyzed using IBM SPSS software package version 20.0. ${ }^{(2)}$ Quantitative data were described using range (minimum and maximum), mean, standard deviation and median. Significance of the obtained results was judged at the 5\% level. The used tests were, Student t-test for normally quantitative variables, to compare between two studied groups. F-test (ANOVA) for normally quantitative variables, to compare between more than two groups, and Post Hoc test (LSD) for pairwise comparisons. Mann Whitney test For abnormally quantitative variables, to compare between two studied groups. Kruskal Wallis test For abnormally quantitative variables, to compare between more than two studied groups.

\section{Results}

There was metallic ions released from both titanium and cobalt chromium the result of ions released from cobalt after 7 days is shown in Table 3. There was statistically significant different between normal and acidic groups and between alkaline and acidic groups $\mathrm{p}$ - value $<0.001^{*}$ and was not statistically significant between normal and alkaline groups.

Table 3: Comparison between the different groups according to cobalt ions released (ppm) after 7 days

\begin{tabular}{|c|c|c|c|c|c|}
\hline 7days & $\begin{array}{c}\text { Normal } \\
(\mathbf{n = 3})\end{array}$ & $\begin{array}{c}\text { Acidic } \\
(\mathbf{n = 3})\end{array}$ & $\begin{array}{c}\text { Alkaline } \\
(\mathbf{n}=\mathbf{3})\end{array}$ & $\mathbf{F}$ & $\mathbf{p}$ \\
\hline Cobalt (ppm) & & & & \multirow{2}{*}{$51.508^{*}$} \\
\hline Min. - Max. & $0.2757-0.2932$ & $0.3649-0.4101$ & $0.2721-0.2841$ & $<0.001^{*}$ \\
\hline Mean \pm SD. & $0.2838 \pm 0.0088$ & $0.3864 \pm 0.0227$ & $0.2799 \pm 0.0067$ & \\
\hline Median & 0.282 & 0.3842 & 0.2834 & \\
\hline Sig.bet,grop. & \multicolumn{2}{|c|}{$\mathrm{p}_{1}<0.001^{*}, \mathrm{p}_{2}=0.754, \mathrm{p}_{3}<0.001^{*}$} & \\
\hline
\end{tabular}

F: F value for ANOVA test for Post Hoc Test (LSD) p1 : p value for comparing between normal group and acidic group

$\mathrm{p}_{2}: \mathrm{p}$ value for comparing between normal group and alkaline group

$\mathrm{p}_{3}: \mathrm{p}$ value for comparing between alkaline group and acidic group

*: Statistically significant at $\mathrm{p} \leq 0.05$
The result of ions released from cobalt after 30 days is shown in Table 4. There was statistically significant different between normal and acidic

groups and between alkaline and acidic groups p- value $<0.001 *$ and was not statistically significant between normal and alkaline groups. 


\section{International Journal of Science and Research (IJSR) \\ ISSN (Online): 2319-7064 \\ Index Copernicus Value (2013): 6.14 | Impact Factor (2015): 6.391}

Table 4: Comparison between the different groups according to cobalt ion released (ppm) after 30 days

\begin{tabular}{|c|c|c|c|c|c|}
\hline 30 days & Normal $(\mathbf{n = 3})$ & Acidic $(\mathbf{n = 3})$ & Alkaline $(\mathbf{n}=\mathbf{3})$ & F & p \\
\hline Cobalt (ppm) & & & & \\
\hline Min. - Max. & $0.3793-0.3930$ & $0.4308-0.5026$ & $0.3278-0.3621$ & \multirow{2}{*}{$19.816^{*}$} & \multirow{2}{*}{$0.002^{*}$} \\
\hline Mean \pm SD. & $0.3862 \pm 0.0069$ & $0.4700 \pm 0.0364$ & $0.3497 \pm 0.0190$ & & \\
\hline Median & 0.3862 & 0.4767 & 0.3591 & & \\
\hline Sig.bet,grop. & & $\mathrm{p}_{1}=0.005^{*}, \mathrm{p}_{2}=0.112, \mathrm{p}_{3}=0.001^{*}$ & & \\
\hline
\end{tabular}

F: F value for ANOVA test for Post Hoc Test (LSD)

$\mathrm{p} 1: \mathrm{p}$ value for comparing between normal group and acidic group

p2: p value for comparing between normal group and alkaline group

p3 : p value for comparing between alkaline group and acidic group

*: Statistically significant at $\mathrm{p} \leq 0.05$

The result of ions released from chromium after 7 days is shown in Table 5. There was statistically significant different between normal and acidic groups and between alkaline and acidic groups $\mathrm{p}$ - value $<0.001 *$ and was not statistically significant between normal and alkaline groups.

Table 5: Comparison between the different groups according to chromium ions released (ppm) after 7 days

\begin{tabular}{|c|c|c|c|c|c|}
\hline 7days & $\begin{array}{c}\text { Normal } \\
(\mathbf{n = 3})\end{array}$ & $\begin{array}{c}\text { Acidic } \\
(\mathbf{n = 3})\end{array}$ & $\begin{array}{c}\text { Alkaline } \\
(\mathbf{n = 3})\end{array}$ & $\mathbf{K} \mathbf{w} \chi^{\mathbf{2}}$ & $\mathbf{p}$ \\
\hline Chromium(ppm) & & & & & \\
\hline Min. - Max. & $0.0331-0.0392$ & $0.080-0.090$ & $0.0333-0.0391$ & \multirow{2}{*}{$6.054^{*}$} & \multirow{2}{*}{$0.048^{*}$} \\
\hline Mean \pm SD. & $0.0356 \pm 0.0032$ & $0.083 \pm 0.0058$ & $0.0362 \pm 0.0029$ & & \\
\hline Median & 0.0346 & 0.08000 & 0.0361 & & \\
\hline Sig.bet.Grps & \multicolumn{2}{|c|}{$\mathrm{p}_{1}=0.043^{*}, \mathrm{p}_{2}=0.456, \mathrm{p}_{3}=0.042^{*}$} & & \\
\hline
\end{tabular}

$\mathrm{Kw} \chi^{2}$ : Kruskal Wallis test for comparing between the different studied groups

$\mathrm{p}_{1}: \mathrm{p}$ value for comparing between normal group and acidic group

$\mathrm{p}_{2}$ : $\mathrm{p}$ value for comparing between normal group and alkaline group

$\mathrm{p}_{3}: \mathrm{p}$ value for comparing between alkaline group and acidic group

*: Statistically significant at $\mathrm{p} \leq 0.05$

The result of ions released from chromium after 30 days is shown in Table 6. There was statistically significant different between normal and acidic groups and between alkaline and acidic groups p- value $<0.001^{*}$ and was not statistically significant between normal and alkaline groups.

Table 6: Comparison between the different groups according to chromium ions released (ppm) after 30 days

\begin{tabular}{|c|c|c|c|c|c|}
\hline 30 days & Normal $(\mathbf{n}=\mathbf{3})$ & Acidic $(\mathbf{n}=\mathbf{3})$ & Alkaline $(\mathbf{n}=\mathbf{3})$ & $\mathbf{K}$ & $\mathbf{2}$ \\
\hline Chromium(ppm) & & & & \\
\hline Min. - Max. & $0.2800-0.3200$ & $0.5400-0.5800$ & $0.2700-0.3000$ & \multirow{2}{*}{$6.006^{*}$} \\
\hline Mean \pm SD. & $0.3067 \pm 0.0231$ & $0.5600 \pm 0.0200$ & $0.2867 \pm 0.0153$ & \multirow{2}{*}{$0.049^{*}$} \\
\hline Median & 0.3200 & 0.5600 & 0.2900 & \\
\hline Sig.bet.Grps & \multicolumn{2}{|c|}{$\mathrm{p}_{1}=0.046^{*}, \mathrm{p}_{2}=0.268, \mathrm{p}_{3}=0.050^{*}$} & & \\
\end{tabular}

$\mathrm{Kw} \chi^{2}$ : Kruskal Wallis test for comparing between the different studied groups

$\mathrm{p}_{1}: \mathrm{p}$ value for comparing between normal group and acidic group

$\mathrm{p}_{2}: \mathrm{p}$ value for comparing between normal group and alkaline group

$\mathrm{p}_{3}$ : $\mathrm{p}$ value for comparing between alkaline group and acidic group

*: Statistically significant at $\mathrm{p} \leq 0.05$

The result of ions released from anodizing titanium after 7 days is shown in Table 7. There was statistically significant different between normal and acidic groups and between

alkaline and acidic groups $\mathrm{p}$ - value $<0.001^{*}$ and was not statistically significant between normal and alkaline groups.

Table 7: Comparison between the different groups according to titanium ions released (ppm) after 7 days

\begin{tabular}{|c|c|c|c|c|c|}
\hline 7days & Normal $(\mathbf{n}=\mathbf{3})$ & Acidic $(\mathbf{n}=\mathbf{3})$ & Alkaline $(\mathbf{n}=\mathbf{3})$ & $\mathbf{K w} \chi^{\mathbf{2}}$ & $\mathbf{p}$ \\
\hline Titanium (ppm) & & & & \\
\hline Min. - Max. & $0.0-0.0$ & $0.0030-0.0033$ & $0.0-0.0$ & \multirow{3}{*}{$7.714^{*}$} & \multirow{2}{*}{$0.021^{*}$} \\
\hline Mean \pm SD. & $0.0 \pm 0.0$ & $0.0031 \pm 0.0002$ & $0.0 \pm 0.0$ & & \\
\hline Median & 0.0 & 0.0030 & 0.0 & & \\
\hline Sig.bet,grop. & \multicolumn{3}{|c|}{$\mathrm{p}_{1}=0.034^{*}, \mathrm{p}_{2}=1.000, \mathrm{p}_{3}=0.034^{*}$} \\
\hline
\end{tabular}

$\mathrm{Kw} \chi^{2}$ : Kruskal Wallis test for comparing between the different studied groups

$\mathrm{p} 1: \mathrm{p}$ value for comparing between normal group and acidic group

p2 : p value for comparing between normal group and alkaline group

$\mathrm{p} 3$ : $\mathrm{p}$ value for comparing between alkaline group and acidic group

*: Statistically significant at $\mathrm{p} \leq 0.05$ 


\section{International Journal of Science and Research (IJSR) \\ ISSN (Online): 2319-7064 \\ Index Copernicus Value (2013): 6.14 | Impact Factor (2015): 6.391}

The result of ions released from anodizing titanium after 30 days is shown in Table 8 . There was statistically significant different between normal and acidic groups and between alkaline and acidic groups p- value $<0.001^{*}$ and was not statistically significant between normal and alkaline groups.

Table 8: Comparison between the different groups according to titanium ions released (ppm) after 30 days

\begin{tabular}{|c|c|c|c|c|c|}
\hline 30 days & Normal $(\mathbf{n}=\mathbf{3})$ & Acidic $(\mathbf{n}=\mathbf{3})$ & Alkaline $(\mathbf{n}=\mathbf{3})$ & $\mathbf{K} w \chi^{\mathbf{2}}$ & $\mathbf{p}$ \\
\hline Titanium $(\mathbf{p p m})$ & & & & & \\
\hline Min. - Max. & $0.0061-0.0062$ & $0.0081-0.0082$ & $0.0060-0.0061$ & & \multirow{2}{*}{$0.033^{*}$} \\
\hline Mean \pm SD. & $0.0061 \pm 0.0001$ & $0.0081 \pm 0.0001$ & $0.0060 \pm 0.0001$ & \multirow{2}{*}{$6.830^{*}$} & \\
\hline Median & 0.0061 & 0.0081 & 0.0060 & & \\
\hline
\end{tabular}

$\mathrm{Kw} \chi^{2}:$ Kruskal Wallis test for comparing between the different studied groups

$\mathrm{p} 1: \mathrm{p}$ value for comparing between normal group and acidic group

$\mathrm{p} 2: \mathrm{p}$ value for comparing between normal group and alkaline group

p3 : p value for comparing between alkaline group and acidic group

*: Statistically significant at $\mathrm{p} \leq 0.05$

The result of SEM for the control group for scanning (before immersion in artificial saliva) are shown in (fig $2 \mathrm{a}, \mathrm{b}$ ) both the titanium and cobalt chromium were smooth.

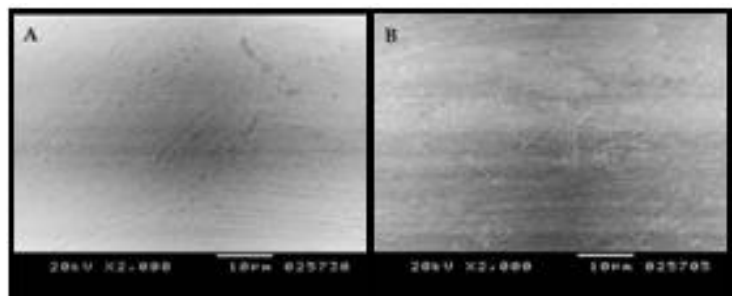

Figure (2a, b): SEM of control group. a) cobalt chronmium, b) titanium

The surface morphology of normal group of cobalt chromium for SEM is shown in (fig. 3a) the micrograph showed pit attacking with cracks.

The surface morphology of normal group of titanium for SEM is shown in (fig. 3b) the micrograph showed cracks on the surface.

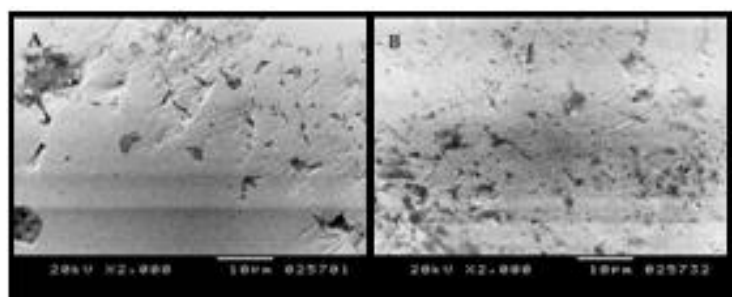

Figure (3a, b): SEM of normal group. a) cobalt chronmium, b) titanium.

The surface morphology of alkaline group of cobalt chromium for SEM is shown in (fig. 4a) the micrograph showed pit attacking with crack.

The surface morphology of alkaline group of titanium for SEM is shown in (fig. 4b) the micrograph showed surface resemble surface of control group.

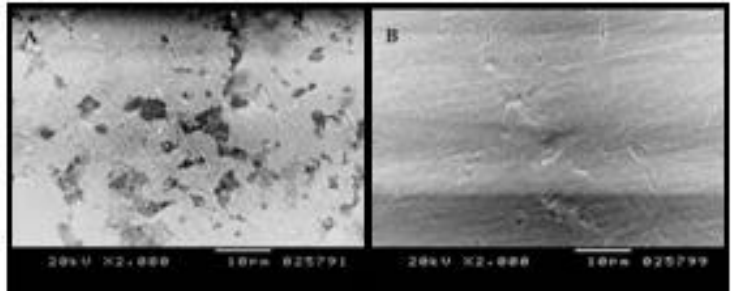

Figure (4a, b): SEM of alkaline group. a) cobalt chronmium, b) titanium.

The surface morphology of acid group of cobalt chromium for SEM is shown in (fig. 5a) the micrograph showed aggressive pores with dissolution and damaged surface which demonstrate there was aggressive corrosion.

The surface morphology of acid group of titanium for SEM is shown in (fig. 5b) the micrograph showed pit and crack more than control group.

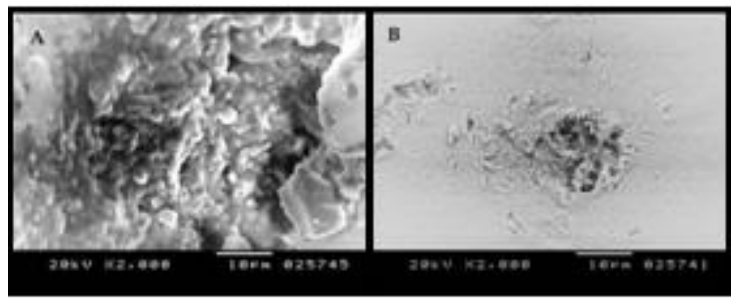

Figure (5a, b): SEM of acid group. a) cobalt chronmium, b) titanium

\section{Discussion}

Titanium alloys (TI6AI4A) alloys coexist with cobalt chromium and different metallic superstructures and other dental restoration in patient mouth. under these conditions galvanic corrosion phenomena can occur and that possibility cannot discarded when determining the appropriate treatment for a specific patient [20-22] so in this study used titanium and cobalt chromium in contact with each other. Anodic oxidation is a surface improvement technique for implants, Passive layers which are formed during anodic oxidation are more stable than oxide layers which are formed on the alloy surface in contact with air $[23,24]$ So anodizing titanium (was preferred to be used in this study to improve the corrosion behavior. Corrosion of dental alloys may have biological, functional and aesthetic effects. [25] According to Hsu et al [26] until 2004 only a few article on the corrosion behavior of titanium implant 


\section{International Journal of Science and Research (IJSR) \\ ISSN (Online): 2319-7064}

Index Copernicus Value (2013): 6.14 | Impact Factor (2015): 6.391

alloys in human body fluid could be found in literature, but the number has increased in the last years. [27-31] So the purpose of this study was to investigate the corrosion resistance of anodizing TI6AI4V titanium dental implant with Cobalt chromium bar attachment. in vitro study have been used because the quantity of corrosion product released from dental alloys in vivo has not been measured, because there is no method available for direct measurement of corrosion released in vivo over extended period. [32] Immersion time is time during which titanium implant and cobalt chromium bar materials are submerged in artificial saliva were 7 and 30 days. 7 days Short immersion time testing (several hours to several days) is used in order to compare amounts of released ions from different metallic materials. Medium immersion time (several days to several weeks) used in study was 30. [33] The current study was conducted on nine specimens (each specimens two titanium dental implant with cobalt chromium bar) forming three groups: group $\mathrm{A}$ three specimens in normal $\mathrm{pH}$ saliva, group $\mathrm{B}$ three specimens in acidic $\mathrm{pH}$ saliva, group $\mathrm{C}$ three specimens in alkaline $\mathrm{pH}$ saliva. In present study the specimens were immersed in artificial saliva. Artificial saliva is often used in vitro studies because of its greater accessibility and chemical stability compared to natural medium. [34] Media (artificial saliva) used in this study because when two or more dental prosthesis made of dissimilar alloys come in contact while exposed to oral fluids (saliva), the difference between their potential result in flow of electrical current between them, galvanic cell is formed and galvanic current cause acceleration of corrosion of less noble metal, (the current flow through two electrolytes, saliva or other liquid in the mouth). [35] Artificial saliva, it was used in this study at $37^{\circ}$ to mimic temperature of oral cavity and at different $\mathrm{pH}$ concentration. The $\mathrm{PH}$ influence the type and amount of metallic ions release from dental alloys .most corrosion studies have been performed at low $\mathrm{pH}$, for example 1, 2.3, or 4.2. This may have made the results not compatible with physiological conditions. [36,37] Therefore, different $\mathrm{pH}$ concentration was used in this study to closely mimic human saliva .which in the mouth, alloys may be exposed to transient $\mathrm{pH}$ changes, either from foods or plaque. [38] Measuring ion leakage is one way to estimate corrosion process, so atomic emission Spectrophotometer (ICP) was used in this study to determined concentration of metallic ions released in artificial saliva. Atomic emission spectrophotometer is sensitive analytic technique, all elements can be determined and identified with rapid analysis. [39] Scanning electron microscopic characterize surface-topography qualitatively and has high resolution as well as large depth of focus, so used in this study at different magnification. [40] The result of this study revealed that the concentration of metallic ions released from cobalt chromium and titanium increased with increase time of immersion and decreased in $\mathrm{pH}$ value, this result supported by Ivana D. Dimic et.al 2013, [41] reported that metallic ions concentration increased with increasing immersion time and decreased of the $\mathrm{pH}$ value. Nuoh $\mathrm{T}$, Andre Mars J et.al 2015 [42] demonstrate corrosion rate aggravated in acidic $\mathrm{pH}$ media. Another study demonstrates opposite results, with greater amount of ions released at normal $\mathrm{pH}$ value [43] and this result not agreement with our study. in 7 days the result obtained from this study showed that most concentration of metallic ions released was in cobalt in acidic $\mathrm{pH}$ artificial saliva and less or no released metallic ions was in titanium, there was significant difference between (normal, alkaline) and acid, and not statistically significant between normal and alkaline group. This result agree with, Suto et al 2013 [44] demonstrated in an immersion study of TI in artificial saliva of varying $\mathrm{pH}$ in contact with dissimilar metal the lower the $\mathrm{pH}$ and the longer the immersion time, the greater the amount of ions release. Amal A.EL Sawy 2013 [45] evaluated the metal ion release from titanium and co-cr-mo casting alloys, showed there was increase in ion concentration of different elements for both alloys, and most released ions was cobalt and less one was titanium but not agree with Taher NM, Al Jabab AS 2013. [46] studied Galvanic corrosion behavior of implant suprastructure dental alloys and reported that the titanium was found to be more corrosion than cobalt chromium alloys in connected to titanium implant this conflict may be due to the titanium used in this study was anodizing type which more stable than non anodizing one accordance to Abdullah Afshar et.al 2011 [47] founded the corrosion rate in non-anodizing state is much higher than that in anodized one due to the resistant anodic film on surface on anodized titanium. In 30 days the concentration of metallic ions released from chromium in acidic $\mathrm{pH}$ artificial saliva was the most, this may be due to breakdown of passive layer which formed on chromium in short immersion time. And also there was increased in concentration of cobalt and titanium metallic ions release, which was statistically significant between (normal, alkaline) and acid, and statistically not significant between normal and alkaline The SEM results showed the surface of titanium and cobalt chromium before immersion period was smooth. and after immersion period there was corrosion attack the surface of cobalt chromium more than the surface of titanium and it was extremely in acidic $\mathrm{pH}$ artificial saliva and less in both normal and alkaline one no significant change was observed in the SEM image of titanium in both normal and alkaline group and control group (before immersion period), this may be due to passive oxide layer formed on the surface of titanium more stable than passive layer formed on cobalt chromium and also anodic oxidation process improve corrosion resistant of titanium agree with Archana Singh et.al 2013 [48] which found the corrosion as well as pitting resistance of titanium highest in the anodized surface as compared to that on the unanodized surface. This study agree with suleyman hakan tuna et al 2009 [49] in which showed that the surface of superstructures cobalt chromiumr were extremely prone to corrosion than titanium.

\section{Conclusion}

This study was performed to evaluate the effect of $\mathrm{pH}$ change on the corrosion resistance of anodizing titanium dental implant with cobalt chromium bar attachment. The results showed statically difference between groups, the less corrosion resistance at lowest $\mathrm{pH}$ artificial saliva. It could be concluded that the corrosion resistance of both titanium and cobalt chromium affected by $\mathrm{pH}$ change, in which less corrosion resistance appeared in low $\mathrm{pH}$ media.

\section{References}

[1] G. Ağaoğlu, T, Arun, B, Izgi, A. Yarat, "Nickel and chromium levels in the saliva and serum of patient with fixed orthodonyic appliances and serum of 


\section{International Journal of Science and Research (IJSR) \\ ISSN (Online): 2319-7064}

Index Copernicus Value (2013): 6.14 | Impact Factor (2015): 6.391

patient with fixed orthodontic appliance," Angle orthod, 71, pp. 375-379, 2001.

[2] C, Ohkubo, S, Hanatani, T, Hosoi, "Present status of titanium removable denture a review of literature," J Oral Rehabil, 35, pp. 706-714, 2008.

[3] R.G. Craig, "Composition, Characteristics and Clinical and Tissue Reactions of Impression Materials. In: Smith DC, Williams DF (eds). Biocompatibility of Dental Materials, Vol. Ill, Boca Raton, Florida: CRC Press, pp. 227-298, 1982.

[4] R, Zupancic, F.N. Legat, "Tensile strength and corrosion resistance of brazed and laser-welded cobaltchromium alloys joints," J Prosthet Dent, 96, pp. 273282, 2006.

[5] Hille GH. Titanium for surgical implant. J Mat 1966; 1: 373-83.

[6] H. Tscherrnitschek, L. Borchers, W. Geurtsen, "Nonalloyed titanium as a bioinert metal: A review," Quntessence Int, 36, pp. 523-530, 2005.

[7] A. Cizewski, M, Baraniak, M, Urbanek-Brychzynska, "Corrosion by galvanic coupling between amalgam and different chromium-based alloys," Dent Mater, 23, pp. 1256-1261, 2007.

[8] D, Upadhyay, M.A. Panchal, R.S. Dubey, V.K. Srivastava, "Corrosion of alloy used in dentistry: A review, Mater Sci Eng, A432, pp. 1-11, 2006.

[9] G. Ravnholt, "Corrosion current PH rise around titanium implant coupled to dental alloys," Scand J Dent Res, 96, pp. 466-472, 1998.

[10] G. Ravnholt, J. Jensen, "Corrosion investigation of two material for implant. supraconstruction coupled to a titanium implant," Scand Dent Res, 99, pp. 181-186, 1991.

[11] L. Reclaru, J.M. Meyer, "Study of corrosion between a titanium implant and dental alloys," J Dent, 22, pp. 159-168, 1994.

[12] L.D. Zardiackas, M.D. Roach, R.S. Williamson, J.A. Bogan, "Comparison of the notch sensitivity and stress corrosion cracking of a low-nicked stainless steel to 316 LS and 22 cr-13NI-5Mn stainless steels," In: Winters GL, Nutt MJ (eds). Stainless steels for medical and surgical applications. ASTM 1438. West Conshohocken (PA): ASTM International, pp. 154167, 2003.

[13] ASM handbook, volume 13 "CORROSION " ISBN 087170-007-7 ASM International 2003.

[14] P. Kovacs, J.A. Davidson, "Chemical and electrochemical aspects of the biocompatibility of titanium and its alloys," In: Brown SA, Lemons JE, (eds). Medical applications of titanium and its alloys: the materials and biological issues, ASTM STP 1272. pp. 163-178, 1996.

[15] D.M. Brunetee, P. Tengvall, M. Textor, P. Thomsen, "Material science surface science, engineering biological response and medical application," In: Titanium in medicine. $1^{\text {st }}$ ed. Germany: Springer, 2001.

[16] T. Biestek, J. Weber, "Electrolytic and chemical conversion coatings," $1^{\text {st }}$ ed. Portcullis press, pp. 225228, 1976.
[17] R. Narayanan, S.K. Seshadri, "Phosphoric Acid Anodization of TI-6AL-4V-Structure and corrosion aspect," Corros Sci, 49, 542-558, 2007.

[18] M. Pisarek, K.M.G. Dahlke, M.J. Czachor, K.J. Kurzydlowski, "Nanooscale Characterization of anodic oxide films on Ti-6A1-4v alloy, Thin solid films, 515, pp. 6460-6464, 2007.

[19] D.D. Acdonald, M.U. Macdonald, "Theory of steady state passive films," J Electrochemical Soc, 137, pp. 2395-2402, 1990.

[20] S. H. Tuna, N. Pekmez, F. Keyf and F. Canli, "The electrochemical properties of four dental casting suprastructure alloys coupled with titanium implants," J Appl Oral Sci, 17, 467, 2009.

[21] N. Adya, M. Alan, T. Ravindranath, B. Saluja, "Corrosion in titanium dental implants: literature review," J Indian Prosthodont Soc, 3, pp. 126-131, 2005.

[22] H. Arslan, H. Çelikkan, N. Örnek, O. Ozan, A.E. Ersoy, M.L. Aksu, "Galvanic corrosion of titaniumbased dental implant materials," J Appl Electrochem, 38, pp. 853-859, 2008.

[23] R. Narayanan, S.K, Seshadri, "Phosphoric Acid Anodization of Ti-6Al-4V-Structural and Corrosion Aspects," Corros Sci, 49, pp. 542-558, 2007.

[24] M. Pisarek, K. Roldot $\{\backslash h b o x\{z\}\}$ niatowski, M.G. Dahlke, M.J. Czachor, K.J. Kurzydłowski, Nanoscale Characterization of Anodic Oxide Films on Ti-6Al-4V Alloy," Thin Solid Films, 2007, 515, pp 6460-6464.

[25] J. Geis-Gestorfer, "In vitro corrosion measurements of dental alloys," J Dent, 22, pp. 247-251, 1994.

[26] R. W-Wei Hsu, C-C. Hsu Yang, C-An Huang, Yi-Sui Chen, "Electrochemical corrosion properties of $\mathrm{Ti}-$ 6Al-4V implant alloy in the biological environment," Mater Sci Eng A, 380, pp. 100-109, 2004.

[27] H. Arslan, H. Çelikkan, N. Örnek, O. Ozan, A.E. Ersoy, M.L. Aksu, "Galvanic corrosion of titaniumbased dental implant materials," J Appl Electrochem, 38, pp. 853-859, 2008.

[28] T.P. Chaturvedi, "An overview of the corrosion aspect of dental implants (titanium and its alloys)," Indian J Dent Res, 20, pp. 91-98, 2009.

[29] M. Atapour, A.L. Pilchak, M. Shamanian, M.H. Fathi, "Corrosion behavior of Ti-8Al-1Mo-1V alloy compared to Ti-6Al-4V," Mater Des, 32, p. 1692, 2011.

[30] N. A. Al-Mobarak, A.A. Al-Swayih, F.A. Al-Rashoud, "Corrosion B ehavior of Ti-6Al-7Nb Alloy in Biological Solution for Dentistry Applications," Int J Electrochem Sci, 6, pp. 2031-2042, 2011.

[31] G. Ciurescu, J. Izquierdo1, J.J. Santana1, D. Mareci, D. Sutiman, S. González, R.M. Souto, "Characterization of the Localized Surface Chemical Activity of Ti-Mo and Ti-Ta Alloys for Biomedical Applications Using Scanning Electrochemical Microscopy,” Int J Electrochem Sci, 7, pp. 7404-7424, 2012.

[32] L.J. Van Vuuren, J.S. Odendaal, P.C. Pistorius, "Galvanic corrosion of dental cobalt-chromium alloys and dental amalgam in artificial saliva," SADJ, 63(1), pp. 34-8, 2008. 


\section{International Journal of Science and Research (IJSR) \\ ISSN (Online): 2319-7064}

Index Copernicus Value (2013): 6.14 | Impact Factor (2015): 6.391

[33] I. Dimić, "Association of Metallurgical Engineers of Serbia AMES,” Metall Mater Eng, 19(2), pp. 167-176, 2013.

[34] J.Y. Gal, M. Fovet, M. Adib-Yadzi, "About a synthetic saliva for in vitro studies," Talanta, 53(6), pp. 1103-1115, 2001.

[35] Tb chatyrvedi vol (20) 2009 p91-98 -1 corrosion aspect of dental implant .

[36] J.D. Bumgardner, B.I. Johansson, "Effect of titaniumdental restoration alloys galvanic couples on culture cells," J Biomed Mater Res, 43, pp. 184-191, 1998.

[37] S.C. Bayne, "Correlation of clinical performance with in vitro tests of restorative dental materials that use polymer-based matrices," Dent Mater, 28, pp. 52-71, 2012.

[38] A. Aamdal-Scheie, W.M. Luan, G. Dahlen, O. Fejerskov, "Plaque $\mathrm{pH}$ and microflora ofdental plaque on sound and carious root surfaces," J Dent Res, 75, pp. 1901-1908, 1996.

[39] M. Batsala, B. Chandu, B. Sakala, S. Nama, S. Domatoti, "Inductive Coupled Plasma Mass Spectrometry (ICP-MS)," Int J Research Pharm Chem, 2(3), pp. 671-680, 2012.

[40] M. Ieland, M. Textor, N.D. Spencer, D.M. Brunette, "Wavelength-dependent roughness: a quantitative approach to characterizing the topography of rough titanium surfaces," Int J Oral Maxillofac Implants, 16, pp. 163-181, 2001.

[41] I.D. Dimić, I.L. Cvijović-Alagić, M.B. Rakin, A.A. Perić-Grujić, M.P. Rakin, B.M. Bugarski, S.S. Putić, "Effect of the $\mathrm{pH}$ of artificial saliva on ion release from commercially pure titanium," Acta Periodica Technologica, 44, pp. 207-215, 2013.

[42] T. Nuoh, J. Andre Mars, N. Thovhogi, D. Gihwala, A.A. Baleg, M. Maaza, "Influence of Temperature and $\mathrm{pH}$ on Corrosion Resistance of $\mathrm{Ni}-\mathrm{Cr}$ and $\mathrm{Co}-\mathrm{Cr}$ Dental Alloys on Oral Environment," 2015.

[43] M.T. Mathew, S. Abbey, N.J. Hallab, D.J. Hall, C. Sukotjo, M.A. Wimmer, "Influence of $\mathrm{pH}$ on the tribocorrosion behavior of $\mathrm{CpTi}$ in the oral environment: Synergistic interactions of wear and corrosion," J Biomed Mater Res B Appl Biomater, 100, pp. 1662-1671, 2012.

[44] H. Suito, Y. Iwawaki, T. Goto, Y. Tomotake, T. Ichikawa, "Oral factors affecting titanium elution and corrosion: An in vitro study using simulated body fluid," PLOS One, 8(6), p. e66052, 2013.

[45] A.A. EL Sawy, "Evaluation of metal ion release from titanium and co-cr casting alloys," J Prosthodont, 23(2), pp. 89-97, 2014.

[46] N.M. Taher, A.S. Al Jabab, "Galvanic corrosion behavior of implant suprastructure dental alloys," Dent Mater, 19, pp. 54-59, 2003.

[47] A. Abdollah, "Pure Commercial Titanium Color Anodizing and Corrosion Resistance," J Materi Eng Perform, 20, pp. 1690-1696, 2011.

[48] S. Archana, "Effect of anodization on corrosion behaviour and biocompatibility of $\mathrm{Cp}$-titanium in simulated body fluid," Bull Mater Sci, 36, pp. 931937, 2013.

[49] S.H. Tuna, N.O. Pekmez, F. Keyf, F. Canli, "The electrochemical properties of four dental casting super structure alloys coupled with titanium implants," J Appl Oral Sci, 17(5), pp. 467-475, 2009.

\section{Author Profile}

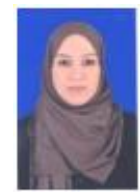

Narjes Fadel Mohsen, received the B.D.S. in Dental and Oral Surgery from Tripoli University, Faculty of dentistry 2007. During 2007-2008, she practiced in Ministry of Health. Since 2009-2012, she worked as a demonstrator in Tripoli University. During 2012 till now, she educated for M.S degree in prosthodontics in prosthetic department, Faculty of dentistry. Alexandria University. 